\title{
Analysis of Emergency Department Admissions with Hypo or Hyperglycemia in the Month of Ramadan
}

\author{
Ramazan Ayında Hipo veya Hiperglisemi ile Acil Servise Başvuran \\ Hastaların Analizi
}

\author{
Ekim SAGLAM GURMEN ${ }^{1}$, Kivanç KARAMAN ${ }^{2}$, Yunus Emre ÖZLÜER ${ }^{3}$, \\ Serkan DOGAN ${ }^{4}$, Dogac Niyazi OZUCELIK ${ }^{5}$ \\ Department of Emergency Medicine, Medical Faculty of Manisa Celal Bayar University, Manisa \\ ${ }^{2}$ Department of Emergency Medicine, Medical Faculty of Süleyman Demirel University, Isparta \\ ${ }^{3}$ Department of Emergency Medicine, Medical Faculty of Adnan Menderes University, Aydın \\ ${ }^{4}$ Istanbul Kanuni Sultan Suleyman Training and Research Hospital, Department of Emergency Medicine, University of Health Sciences, İstanbul \\ ${ }^{5}$ Department of Emergency Medicine, Health Sciences Faculty of Istanbul University, İstanbul
}

\begin{abstract}
$\overline{\text { Öz }}$
Bu çalışma ile Ramazan ayında acil servise başvuran diyabetik hastaların glisemik profilinin ortaya konulması amaçlandı. Acil servise hipo veya hiperglisemi ile başvuran ve oruç tuttuğunu ifade eden, 18 yaş üstü hastaların dosyaları geriye dönük olarak incelendi. Çalışmaya 161 (\%95.3)'i hiperglisemi, 8 (\%4.7)'i hipoglisemi nedeniyle başvuran toplam 169 (139 diyabetik, 30 diyabeti olmayan) hasta dahil edildi. Hastaların kan glukoz düzeyi $36 \mathrm{mg} / \mathrm{dl}$ ile $736 \mathrm{mg} / \mathrm{dl}$ arasında değişirken, ortalama 279 \pm 127 $\mathrm{mg} / \mathrm{dl}$ olarak hesaplandı. $163(\% 96.4)$ hastanın acil servisten taburcu edildiği, $4(\% 2.4)$ vakanın sevk edildiği ve sadece 2 (\%1.2) hastanın hastaneye yatırıldığı görüldü. Ramazan ayında ortaya çıkabilecek metabolik bozukluklar ve semptomlarının titiz takibi ile bilgilendirildikten sonra, diyabetik hastaların herhangi bir ekstra diyet ve ilaç protokolü izlemeden oruç tutabilecekleri görülmektedir. Diyabeti olmayan kişilerde de Ramazan ayında hipo veya hiperglisemi atağı görülebilir. Bu hastaların özellikle prediyabetik durum ve hipo veya hiperglisemiyi tetikleyebilecek altta yatan hastalıklar açısından tetkik edilmesi gereklidir.
\end{abstract}

Anahtar Kelimeler: Diyabet, Oruç, Hiperglisemi, Hipoglisemi

\begin{abstract}
In this study, we aimed to identify the glycemic profile of patients admitted to our emergency department during Ramadan. The charts of patients aged 18 years and over who had been fasting religiously and admitted to the Emergency Service with hyperglycemia or hypoglycemia during the month of Ramadan, were reviewed retrospectively. 169 patients (30 non-diabetic, 139 diabetic) were found to be admitted with hyperglycemia (161 cases, 95.3\%) or hypoglycemia ( 8 cases, $4.7 \%$ ). The blood glucose level ranged from 30 to 736 , with an mean of $279 \pm 127 \mathrm{mg} / \mathrm{dl}$. 163 cases $(96.4 \%)$ were discharged from the hospital, 4 cases $(2.4 \%)$ were referred to another hospital, and only 2 cases $(1.2 \%)$ were hospitalized. After being informed about the metabolic disturbances that might occur during Ramadan and by meticulous follow-up of their symptoms, there is no harm in terms of urgent complications in the religious fasting of diabetes mellitus patients without complying any extra diet or medication protocol. Non-Diabetic patient scan undergo episodes of hypo or hyperglycemia during Ramadan. Such patients should be investigated for the presence of a prediabetic status or an underlying disease that can trigger a hyper or hypoglycemic episode. Keywords: Diabetes Mellitus, Fasting Religiously, Hyperglycemia, Hypoglycemia
\end{abstract}

\section{Introduction}

In long fasting periods, numerous metabolic problems such as hypoglycemia, hyperglycemia, dehydration, and electrolyte imbalance may occur not only in diabetics but also in healthy individuals. Diabetes mellitus is an endocrine and metabolic disorder due to insufficiency or absence of insulin hormone, characterized by chronic hyperglycemia, which leads to disturbances of carbohydrate, protein, and lipid metabolism. Persons with diabetes mellitus should be fed with intervals of 2.5-3 hours. Otherwise, when snacks are skipped, the incidences

\begin{tabular}{|c|c|}
\hline & ORCID No \\
\hline Ekim SAGLAM GURMEN & 0000-0002-8672-6181 \\
\hline Kıvanç KARAMAN & $0000-0002-4105-2785$ \\
\hline Yunus Emre ÖZLÜER & 0000-0001-8297-7525 \\
\hline Serkan DOGAN & 0000-0001-8923-2489 \\
\hline Dogac Niyazi OZUCELİK & 0000-0002-7752-0667 \\
\hline Başvuru Tarihi / Received: & 24.08 .2020 \\
\hline Kabul Tarihi / Accepted : & 14.09.2021 \\
\hline Adres / Correspondence : & Kıvanç KARAMAN \\
\hline $\begin{array}{l}\text { Department of Emergency } \\
\text { Süleyman Demirel University, }\end{array}$ & $\begin{array}{l}\text { Medicine, Medical Faculty of } \\
\text { Isparta }\end{array}$ \\
\hline e-posta / e-mail & kiwanckaraman@gmail.com \\
\hline
\end{tabular}

of hypoglycemia and hyperglycemia increase due to the pathophysiology of the disease. In long fasting periods, drug therapy becomes disorganized and adverse drug interactions may occur in diabetic patients, in whom medication times need to be adjusted meticulously. Since religious fasting is one of the five pillars of Islam, Muslims with diabetes mellitus, even those encountering its severe complications, tend to fast religiously (1). Thus, their metabolic balance might be upset, and they might encounter hypoglycemia, hyperglycemia, diabetic ketoacidosis, or other various complications (2).

In long fasting periods, it is not necessary for an individual who has diabetes to have a metabolic problem; in healthy individuals also, hypoglycemia, dehydration, electrolyte imbalance, etc. may occur, leading them to be admitted to Emergency Services. A study conducted on athletes during Ramadan was concluded with various precautions to minimize the adverse effects of religious fasting on metabolism and athletic performance (3).

Our study aimed to investigate the adverse effects occurring in diabetics and nondiabetics due to fasting in Ramadan and to determine the 
differences between diabetic patients and nondiabetics, together with the differences between those presented with hyperglycemia and hypoglycemia.

\section{Material and Method}

This single-center study was conducted retrospectively between 05 June 2016 and 04 July 2016 with patients admitted to the Emergency Service of Istanbul Kanuni Sultan Suleyman Training and Research Hospital.

The inclusion criteria of the study were as follows; patients admitted to the Emergency Service with either hypoglycemia or hyperglycemia (blood glucose $<70 \mathrm{mg} / \mathrm{dl}$ or $>110 \mathrm{mg} / \mathrm{dl}$ ), patients fasting religiously during Ramadan. Patients who were not fasting religiously at the time of admission, patients diagnosed with final diagnoses such as trauma, cerebrovascular disorder, acute coronary syndrome, and sepsis, in whom symptoms and final diagnoses could not be related to the nutritional habits, and patients aged below 18 years were excluded.

Data related to gender, age, the admission time, the Glasgow Coma Scale Score, the symptoms of the patients during admission, the pulse rate, the systolic and diastolic blood pressure, the blood sugar level, the presence of history of diabetes, the other previous diagnoses and comorbidities of the patients, the medications used, and the clinical outcomes were collected and recorded.

The study was approved by the Ethics Committee of Training and Research Hospital of İstanbul, Emergency Service of Kanuni Sultan Suleyman Hospital (2018.3.9). Informed consent was not required as files were retrospectively screened. The authors declare that they have no conflict of interest.

All authors were involved in designing the study, collecting the data, analyzing the data, writing the manuscript, and confirming the accuracy of the data and the analyses. All authors read and approved the final version of manuscript.

NCSS (Number Cruncher Statistical System) 2007 (Kaysville, Utah, USA) software was used for statistical analysis. To see whether continuous variables conform to the normal distribution curve, The Kolmogorov-Smirnov test was employed. Descriptive statistical methods (mean, standard deviation, median, frequency, ratio, minimum, maximum) were used, as well as the Student's T-test was used for two-group comparisons of variables with normal distribution, and the Mann Whitney U test was used for two-group comparisons of nonnormally distributed variables during comparison of quantitative data. Chi-square test was used for comparison of the qualitative data. Statistical significance was present at the level of $\mathrm{p}<0.05$.

\section{Results}

A total of 725 patients in whom hypoglycemia or hyperglycemia was identified at the time of admission to the Emergency Service during the month of Ramadan were investigated. Among these patients, 447 patients who were not fasting and 109 patients in whom the admission complaints, symptoms, and final diagnosis were not related to fasting were excluded from the study. Finally, a total of 169 patients, of which $36.7 \%$ were male $(n=62)$ and $63.3 \%$ female $(n=107)$, were included in the study (Figure 1). The mean age was $57.67 \pm 15.10$ years, and within the range between 20 years and 91 years. No history of diabetes mellitus was present in $17.8 \%(n=30)$ of the patients, whereas diabetes was present in the patient history in $82.2 \%(n=139)$. The distribution of the demographic characteristics of the cases was shown in Table 1.

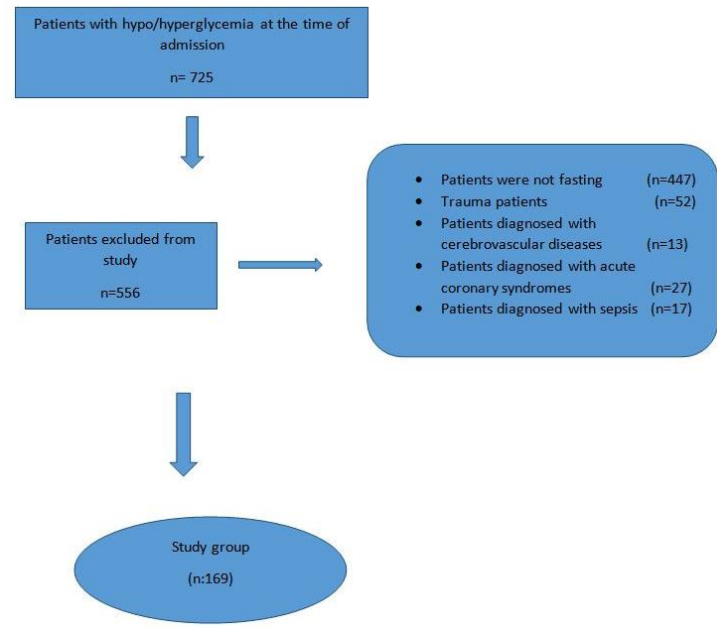

Figure 1. The flow chart fort he constitution of the study group

Table 1. The distribution of the demographic characteristics of the cases

\begin{tabular}{llcc}
\hline \multirow{2}{c}{ Age (years) } & & \multicolumn{2}{c}{ Mean \pm SD } \\
& & \multicolumn{2}{c}{$57.67 \pm 15.10$} \\
n & \% \\
\hline \multirow{2}{*}{ Gender } & Female & 107 & 63.3 \\
& Male & 62 & 36.7 \\
Diabetes Mellitus & Present & 139 & 82.2 \\
Religious Fasting & Absent & 30 & 17.8 \\
\hline
\end{tabular}

The most common complaint was fatigue followed by dizziness, headache, nausea, and vomiting with frequencies of $33.7 \%, 26 \%, 22.5 \%$ and $9.5 \%$ respectively. The measured pulse rates ranged from 50 to 120 beats/minute, with a mean of $82 \pm 11$ beats/minute. The systolic blood pressure measurements ranged from 100 to $252 \mathrm{~mm} \mathrm{Hg}$, with a mean of $134.66 \pm 30.30 \mathrm{~mm} \mathrm{Hg}$. The blood glucose measurements ranged from 30 to 736 , with a mean of $279 \pm 127$.Hyperglycemia was found to be present during admission in $95.3 \%(n=161)$, whereas $4.7 \%$ $(n=8)$ of the cases were presented with 
hypoglycemia. The distributions of the patients according to their clinical features during admission to the Emergency Service were shown in Table 2.

When the medications used by the patients were analyzed, it was determined that $17.2 \%(n=29)$ had not been using any medications. Among the remaining, $43.8 \%(n=74)$ were using insulin, $16.6 \%$ $(n=28)$ various insulin secretagogues, $34.3 \%(n=58)$ metformin, 2.4\% $(n=4)$ glitazones, $7.7 \% \quad(n=13)$ dipeptidyl peptidase 4 inhibitors (DPP-4 Inhibitors), and $30.2 \% \quad(n=51)$ various antihypertensive medications. The distribution of the used medications of the patients was shown in Table 3.

$96.4 \% \quad(n=163)$ of the patients had been discharged from the hospital following symptomatic treatment and observation. Among these patients, 76 (46.6\%) patients underwent follow-up by the Endocrinology Clinic following discharge from the Emergency Service. Two patients (1.2\%) were hospitalized in the Intensive Care Unit, one with the diagnosis of diabetic ketoacidosis, and one due to the hyperosmolar state. Four patients $(2.4 \%)$, in whom regulation of blood sugar was not possible, were referred to another medical center with the purpose of medical management and follow-up by an Endocrinology Department.

When we compared patients regarding the presence of diabetes mellitus in their medical history, there was no statistically significant difference according to age, gender, blood glucose level, outcome and distribution of the admission complaints ( $p>0.05$ ) However, the systolic blood pressure of patients with diabetes history was significantly higher than those with no history of diabetes $(\mathrm{p}<0.05)$ (Table 4).

Since the total number of the cases with hypoglycemia was only8, it was not possible to make accurate comparisons for identification of statistical significance. Even so, various comparisons together with their corrective statistical calculations were performed.

There was no significant difference in pulse rate, systolic and diastolic blood pressure, the presence of diabetes, and clinical outcomes of the patients regarding the existence of hypo or hyperglycemia at admission ( $p>0.05)$. There was no significant difference in blood glucose levels of the patients and the variety of antidiabetic agents they use. The rate of using of insulin, insulin secretagogues, metformin, glitazones, DPP-4 Inhibitors, were determined not to have any significant difference according to their admission blood glucose levels in both hypoglycemic and hyperglycemic patients $(\mathrm{p}>0.05)$ (Table 5).

\section{Discussion}

In this retrospectively designed study, we aimed to analyze the patients, either diabetic or nondiabetic, who were presented to the Emergency
Service due to hypoglycemia or hyperglycemia during the month of Ramadan. We found that hyperglycemia was a much more common cause of admission in both diabetics and non-diabetics.

Diabetes mellitus is a disease necessitating careful follow-up of glucose homeostasis. However, many diabetes patients tend to fast during Ramadan, making it a priority in their life styles (1). One should expect significant turbulence in glucose metabolism, manifesting itself as hypo or hyperglycemia while such patients are either in their fasting state or while they are permitted to eat freely (4). Other diabetic emergencies such as diabetic ketoacidosis, dehydration or thrombosis might also occur, necessitating a population-based consensus on their management (5). Ahmadani et al., in the questionnaire-based survey they had conducted, concluded that all diabetic patients should be counseled regarding time-change of their medications, diet, exercise, and self-monitoring of blood glucose before the onset of fasting in Ramadan (6). Although many individual studies had been warning about the complications of Ramadan fasting, Alabboud et al. reached a contradictory conclusion when they analyzed four major databases, together with hand-searching key journals. They found that the incidence of significant complications was negligible, minor hypoglycemic events did not negatively affect fasting, and the frequency of severe hyperglycemia and diabetic ketoacidosis were trivial (7). Even though its rate is low in our study, six patients $(3.6 \%)$ in whom blood sugar regulation was found to be impaired following fasting were in the red category, two of whom were hospitalized in the Intensive Care Unit.

In the study conducted by Elmehdawi et al. on diabetes patients in Libya, the rates of hypo and hyperglycemia during Ramadan were close to each other (14.6\% vs. $11.2 \%)$ (8). These rates were very far from each other in our study (3.6\% vs. $96.4 \%)$. However, since our study included only the patients admitted to the Emergency Service due to various complaints, we cannot make any suggestions on the actual incidence of hypoglycemia and hyperglycemia in diabetic patients during Ramadan in the Turkish community.

Non-diabetic patients should not necessarily be at an optimum health status regarding the blood glucose level. In our study, we had a number of nondiabetic patients presented with hyperglycemia and hypoglycemia. Nevertheless, non-diabetic patients should not be expected to present frequently with hyperglycemia because of such religious fasting; the supposed reason for admission would more likely be hypoglycemia due to a prolonged fasting state. However, Pallayova et al. reported their study results, which were contrary to such expectations. They performed continuous glucose monitoring before, in the middle of, and after Ramadan, and found a tendency to hyperglycemia, particularly 
Table 2. Distributions of the patients according to their features during admission to the emergency service

\begin{tabular}{|c|c|c|c|}
\hline & & & \\
\hline Systolic Blood Pressur & nHg) & & \\
\hline Diastolic Blood Pressu & mHg) & & \\
\hline Pulse Rate & & & \\
\hline Blood Glucose & & & \\
\hline & & $\mathbf{n}$ & $\%$ \\
\hline & Fatigue & 57 & 33.7 \\
\hline & Dizziness & 44 & 26.0 \\
\hline & Headache & 38 & 22.5 \\
\hline & Nausea-Vomiting & 16 & 9.5 \\
\hline Admission Complaint & Abdominal Pain & 8 & 4.7 \\
\hline & Seizure & 2 & 1.2 \\
\hline & Chest Pain & 2 & 1.2 \\
\hline & Dyspnea & 1 & 0.6 \\
\hline & Numbing of Hands and Feet & 1 & 0.6 \\
\hline Blood Glucose & Hyperglycemia & 161 & 95.3 \\
\hline & Hypoglycemia & 8 & 4.7 \\
\hline
\end{tabular}

Table 3. The distribution of the medications used

\begin{tabular}{lcc}
\hline & $\mathbf{n}$ & $\mathbf{\%}$ \\
Using none & 29 & 17.2 \\
Using & 140 & 82.8 \\
•Insulin & 74 & 43.8 \\
•Metformin & 58 & 34.3 \\
•Antihypertensive & 51 & 30.2 \\
•Insulin Secretagouges & 28 & 16.6 \\
•DPP-4 Inhibitors & 13 & 7.7 \\
•Glitazones & 4 & 2.4 \\
\hline More than one medication can be marked
\end{tabular}

Table 4. Comparison of diabetic and non-diabetic patients

\begin{tabular}{llccc}
\hline & & \multicolumn{2}{c}{ History of Diabetes Mellitus } \\
Demographic & & Absent (n=30) & Present (n=139) & P Value \\
\cline { 2 - 4 } properties & Age (years) & $57.00 \pm 17.27$ & $57.81 \pm 14.65$ & 0.790 \\
& Gender (Male/Female) & $11 / 19$ & $51 / 88$ & 0.419 \\
Vital signs & Systolic Blood Pressure (mmHg) & $120(100-200)$ & $120(100-252)$ & $\mathbf{0 . 0 2 9}$ \\
& Diastolic Blood Pressure (mmHg) & $72(50-110)$ & $74(50-140)$ & 0.188 \\
& Pulse Rate (beat per minute) & $80(60-120)$ & $76(11-115)$ & 0.636 \\
Admission & Dizziness & $12(40.0 \%)$ & $32(23.0 \%)$ & $49(35.3 \%)$ \\
complaints & Fatigue & $8(26.7 \%)$ & $33(23.7 \%)$ & 0.413 \\
& Headache & $5(16.7 \%)$ & $13(9.4 \%)$ & $12(8.6 \%)$ \\
Clinical outcomea-Vomiting & Other Complaints & $3(10.0 \%)$ & $134(96.4 \%)$ \\
& Discharged from the Emergency Service & $29(96.7 \%)$ & $3(2.2 \%)$ \\
\hline
\end{tabular}

Table 5. The Evaluation of the admission time to the emergency service, general health status, and medications of the patients according to the glycemic status of the patients

\begin{tabular}{|c|c|c|c|c|}
\hline & & \multicolumn{2}{|c|}{ Blood Glucose Level } & \multirow{2}{*}{$\begin{array}{c}\text { Test Value } \\
\text { P }\end{array}$} \\
\hline & & $\begin{array}{c}\text { Hypoglycemia }(n=8) \\
n(\%)\end{array}$ & $\begin{array}{c}\text { Hyperglycemia } \\
(\mathrm{n}=161) \\
\mathrm{n}(\%)\end{array}$ & \\
\hline \multirow{2}{*}{ Medication } & Absent & $3(37.5)$ & $26(16.1)$ & \multirow{2}{*}{0.139} \\
\hline & Present & $5(62.5)$ & $135(83.9)$ & \\
\hline \multirow{2}{*}{ Insulin } & Absent & $5(62.5)$ & $90(55.9)$ & \multirow{2}{*}{1.000} \\
\hline & Present & $3(37.5)$ & $71(44.1)$ & \\
\hline \multirow{2}{*}{ Insulin Secretagogue } & Absent & $8(100.0)$ & $133(82.6)$ & \multirow{2}{*}{0.355} \\
\hline & Present & $0(0.0)$ & $28(17.4)$ & \\
\hline \multirow{2}{*}{ Metformin } & Absent & $7(87.5)$ & $104(64.6)$ & \multirow{2}{*}{0.266} \\
\hline & Present & $1(12.5)$ & $57(35.4)$ & \\
\hline \multirow{2}{*}{ Glitazone } & Absent & $7(87.5)$ & $158(98.1)$ & \multirow{2}{*}{0.178} \\
\hline & Present & $1(12.5)$ & $3(1.9)$ & \\
\hline \multirow{2}{*}{ DPP-4 Inhibitors } & Absent & $8(100.0)$ & $148(91.9)$ & \multirow{2}{*}{1.000} \\
\hline & Present & $0(0.0)$ & $13(8.1)$ & \\
\hline \multirow{2}{*}{ Antihypertensive } & Absent & $7(87.5)$ & $111(68.9)$ & \multirow{2}{*}{0.438} \\
\hline & Present & $1(12.5)$ & $50(31.1)$ & \\
\hline
\end{tabular}


after Ramadan. They concluded that insulin sensitivity might have changed due to altered lifestyle pattern encountered by the individuals during Ramadan (9). Our results were consistent with Pallayova's results and conclusion. The number of our non-diabetic patients in whom the admission blood glucose was at the hyperglycemic level was higher than those with hypoglycemia.

Non-diabetic patients having various disorders such as hepatic, renal, or cardiac failure, together with seemingly-well individuals with endogenous hyperinsulinism due to multiple causes, and those with hormonal deficiencies are at risk for developing hypoglycemia. Chihaoui et al., in their prospective study on adult patients with adrenal insufficiency who were fasting in Ramadan, reported that their interstitial glucose levels were lower than normal and asymptomatic hypoglycemia was present in some of them (10). In our study, there were nondiabetic patients who were presented with hypoglycemia; however, the number of non-diabetic hypoglycemic individuals was minimal.

Since we were unable to find a study in the medical literature involving all patients (diabetic and non-diabetic) related to the glycemic status during Emergency Service admissions in Ramadan, we can only make suggestions and comparisons referring to studies conducted on diabetic and non-diabetic patients separately. Moreover, the studies on religious fasting of non-diabetic patients are few, making it more challenging to make definitive comparisons.

When we compared our diabetic patients with non-diabetics regarding the variables that were recorded, we found significant differences in systolic blood pressure which is consistent with the clinical features of the disease. Comorbidities being more common in diabetics are also compatible with the clinical features of diabetes. While dizziness was found to constitute $40 \%$ of the admission symptoms in non-diabetic patients, fatigue and tiredness were present in $35.3 \%$ of the diabetic patients as the admission symptoms. However, in general, $33.7 \%$ of the patients had fatigue, and $26 \%$ had dizziness at the time of admission. In our study, we determined that patients were presented to the Emergency Service with nonspecific complaints such as headache, fatigue-tiredness, and dizziness due to alterations in nutritional habits, and these were found to be related to no condition other than the change in the glycemic state. We determined that nonspecific complaints such as fatigue, tiredness, headache, and dizziness, which were common reasons for admission to the Emergency Service were diagnosed and solved quickly by performing a qualified physical examination and blood sugar measurement. 11.
In conclusion, numerous studies have been performed about the metabolic and health issues of patients with diabetes who were fasting religiously during Ramadan, and additionally, many guidelines have been published on the diet and therapies related to such patients. Most of these studies have reported severe metabolic disturbances and health issues that should be taken care of. However, our study did not reveal such severe clinical features and outcomes. We suggest that by meticulous follow-up of their symptoms, after being informed about the metabolic disturbances that might occur during Ramadan, there is no harm in terms of urgent complications in the religious fasting of diabetes mellitus patients without complying any extra diet or medication protocol. Patients not having diabetes can undergo episodes of hypoglycemia or hyperglycemia during Ramadan. Such patients should be investigated for the presence of a prediabetic status or an underlying disease that can trigger a hyper or hypoglycemic episode.

Ethics Committee Approval: The study was approved by the Ethics Committee of Training and Research Hospital of İstanbul, Emergency Service of Kanuni Sultan Suleyman Hospital (2018.3.9).

\section{References}

1. Ghouri N, Gatrad R, Sattar N, Dhami S, Sheikh A. Summerwinter switching of the Ramadan fasts in people with diabetes living in temperate regions. Diabet Med. 2012;29:696-7.

2. Raveendran AV, Zargar AH. Diabetes control during Ramadan fasting. Cleve Clin J Med. 2017;84:352-6.

3. Shephard RJ. Ramadan and sport: minimizing effects upon the observant athlete. Sports Med. 2013;43:1217-41.

4. Afandi B, Kaplan W, Al Hassani N, Hadi S, Mohamed A. Correlation between pre-Ramadan glycemic control and subsequent glucose fluctuation during fasting in adolescents with Type 1 diabetes. J Endocrinol Invest. 2017;40:741-4

5. Ahmad J, Pathan MF, Jaleel MA, Fathima FN, Raza SA, Khan AK, et al. Diabetic emergencies including hypoglycemia during Ramadan. Indian J Endocrinol Metab. 2012;16:512-5.

6. Ahmadani MY, Riaz M, Fawwad A, Hydrie MZ, Hakeem R, Basit A. Glycaemic trend during Ramadan in fasting diabetic subjects: a study from Pakistan. Pak J Biol Sci. 2008;11:2044-7.

7. Alabbood MH, Ho KW, Simons MR. The effect of Ramadan fasting on glycaemic control in insulin-dependent diabetic patients: A literature review. Diabetes Metab Syndr 2017;11:83-7.

8. Elmehdawi RR, Mukhtad NA, Allaghi NI, Elmajberi SJ. Fasting of Ramadan in peoples with diabetes in Benghazi, Libya: an exploratory study. Libyan J Med 2010, 5: 5036.

9. Pallayova M, Zaghloul HB, Arora T, Choudhury SM, Omar OM, Chagoury OL, et al. Investigating physiological glucose excursions before, during, and after Ramadan in adults without diabetes mellitus. Physiol Behav. 2017;179:110-5.

10. Chihaoui M, Grira W, Bettaieb J, Yazidi M, Chaker F, Rejeb $\mathrm{O}$, et al. The risk for hypoglycemia during Ramadan fasting in patients with adrenal insufficiency. Nutrition. 2018;45:99103 . 